\title{
The effects of soft drinks on the released of calcium from the enamel surface
}

\author{
Diandra Audyla Miranti*, Endang Sukartini*, Milly Armilia Andang* \\ *Department of Conservative Dentistry Faculty Of Dentistry Universitas Padjadjaran, Indonesia
}

ABSTRACT

Introduction: Calcium release from the enamel surface is known as enamel demineralisation. Enamel demineralisation is a chemical process of mineral loss from the email structure. One of the factors that cause demineralisation is the presence of acids derived from food or beverages consumed. This study was aimed to determine the effects of soft drinks and the amount of calcium release from the enamel surface. Methods: This study was an in-vitro experimental. The population was extracted maxillary premolars from orthodontics clinics in health centres, hospitals, and private clinics throughout Bandung and Jakarta. As many as 20 crown of maxillary premolars divided into two groups. Dissolved calcium was measured using the Atomic Absorption Spectrophotometry (AAS). Data obtained was tested using an independent t-test. Results: The results showed that the amount of calcium released after exposure of soft drink was higher than soda water. The average amount of calcium released after soft drink exposure was $4122 \mathrm{ppm}$ and soda water was $3492 \mathrm{ppm}$. Conclusion: Soft drink affects the calcium release from the enamel surface.

Keywords: Calcium release, soft drink pH, soft drink effect.

\section{INTRODUCTION}

Teeth are one of the hard tissue structures of the body. Teeth consist of 4 parts, namely enamel, dentin, cementum, and pulp tissue. Enamel is the hardest tooth structure, consisting of $96 \%$ minerals, the remaining $4 \%$ is water and organic material. ${ }^{1}$

Tooth enamel is the outer layer of the dental crown. Enamel is the hardest structure in the skeletal system of the body. ${ }^{1}$ The mineral composing enamel is primarily a hydroxyapatite which is essential for the strength and brittleness of email. The enamel layer is formed almost entirely by calcified calcium salts to appear to be a hard, thin, and clear layer. ${ }^{2}$ Enamel is a hard but not immune to the attrition during mastication even though the tooth enamel is composed of a microscopic mineral-rich ascular network such as calcium phosphate crystals. ${ }^{1,3}$

Calcium $(\mathrm{Ca})$ is the most abundant mineral in the human body, approximately $1.5-2 \%$ of body weight. $99 \%$ of calcium is in hard tissue, bone, tooth, and the rest of the calcium is widespread in the body. ${ }^{4}$ Calcium has a role in the tooth formation. The content of calcium elements in enamel is more common on tooth surfaces than in the inner layers. ${ }^{5}$ Calcium is necessary during the formation of teeth. Lack of calcium can cause susceptibility to the tooth decay. ${ }^{4}$ 
Soft drinks are non-alcoholic drinks that made up from a mixture of carbonated water, phosphoric acid, preservatives, dyes, and sweetener. As much as $86 \%$ of soft drinks are pure water, it is said that soft drinks contain sodium content in this drink. ${ }^{6}$ Various brands of soft drinks that can be found in the market are Coca Cola ${ }^{\circledR}$, Sprite $^{\oplus}$, and Pepsi ${ }^{\circledR}{ }^{7}$

Since the last 20 years the consumption of soft drinks continues to increase sharply. ${ }^{8}$ The increase in consumption is not only applicable in the United States, but also in other countries around the world. Erosion of teeth is reported to increase especially among young people as primary consumers of soft drinks. ${ }^{9}$

The effect of soft drinks on the release of calcium from the surface of the enamel is causing dental erosion. Tooth erosion can occur as a result of continuous contact or exposure between the hard tissues of the teeth with the acid that comes from the body and from outside the body. ${ }^{10,11}$

Based on the above matters, this study was aimed to determine the effects of soft drinks and the amount of calcium release from the enamel surface.

\section{METHODS}

This research was in-vitro experimental. Statistical analysis was conducted using an independent sample t-test. The population was extracted maxillary premolars from orthodontics clinics in health centres, hospitals, and private clinics throughout Bandung and Jakarta. The sample used in this study was as much as 20 maxillary premolar teeth that met the population criteria. The research procedure was performed towards the selected sample of 20 maxillary premolar teeth that divided into 2 different groups. The first group was immersed in soft drink (Coca Cola ${ }^{\circledR)}$ and the second group with soda water for 10 minutes. The results of the solutions of each group were tested using the Atomic Absorption Spectrophotometry (AAS) to see the amount of calcium released from the enamel surface.

\section{RESULTS}

The results obtained from this research showed that the release of calcium from the enamel surface immersed in soft drink was higher than the soda water (as presented in Table 1 and 2 ). The average concentration of calcium in the surface immersed in soft drink was $18.877 \mathrm{ppm}$ and in the soda water was $3.492 \mathrm{ppm}$, while calcium separated purely from the soft drink was $4.122 \mathrm{ppm}$ and from soda water was $3.492 \mathrm{ppm}$.

Statistical calculation from the data obtained was presented in the form of minimum value, maximum value, median, mode, median, and standard deviation of the amount of dissolved calcium dissolved from the enamel surface immersed in both soft drink and soda water.

Table 1. Amount of calcium released from enamel surface immersed on soft drink

\begin{tabular}{ccc}
\hline Soft drink sample & $\mathrm{Ca}$ & Concentration $(\mathrm{ppm})$ \\
\hline Coca Cola $^{\circledR}$ & 0.000 & 14.754 \\
1 & 5.097 & 19.852 \\
2 & 3.441 & 18.196 \\
3 & 5.443 & 20.197 \\
4 & 4.536 & 19.290 \\
5 & 2.909 & 17.663 \\
6 & 4.852 & 19.607 \\
7 & 4.651 & 19.405 \\
8 & 5.083 & 19.837 \\
9 & 4.521 & 19.276 \\
10 & 4.809 & 19.564 \\
\hline Total & 45.34197 & $\mathbf{2 0 7 . 6 4 1 4 7}$ \\
\hline Average & 4.12200 & $\mathbf{1 8 . 8 7 6 5 0}$ \\
\hline
\end{tabular}

Table 2. Amount of calcium released from enamel surface immersed on soda water

\begin{tabular}{ccc}
\hline Soda Water Sample & $\mathrm{Ca}$ & Concentration $(\mathrm{ppm})$ \\
\hline Soda water & 0.00000 & 0.000 \\
1 & 3.75378 & 3.754 \\
2 & 3.64723 & 3.647 \\
3 & 3.67315 & 3.673 \\
4 & 3.85457 & 3.855 \\
5 & 4.09935 & 4.099 \\
6 & 3.73938 & 3.739 \\
7 & 3.86177 & 3.862 \\
8 & 3.89777 & 3.898 \\
9 & 3.95536 & 3.955 \\
10 & 3.92657 & 3.927 \\
\hline Total & 38.40893 & 38.40893 \\
\hline Average & 3.49172 & 3.49172 \\
\hline
\end{tabular}


Figure 1. Amount of calcium released from enamel surface immersed on soft drink



Figure 2. Amount of calcium released from enamel surface immersed on pure soda water

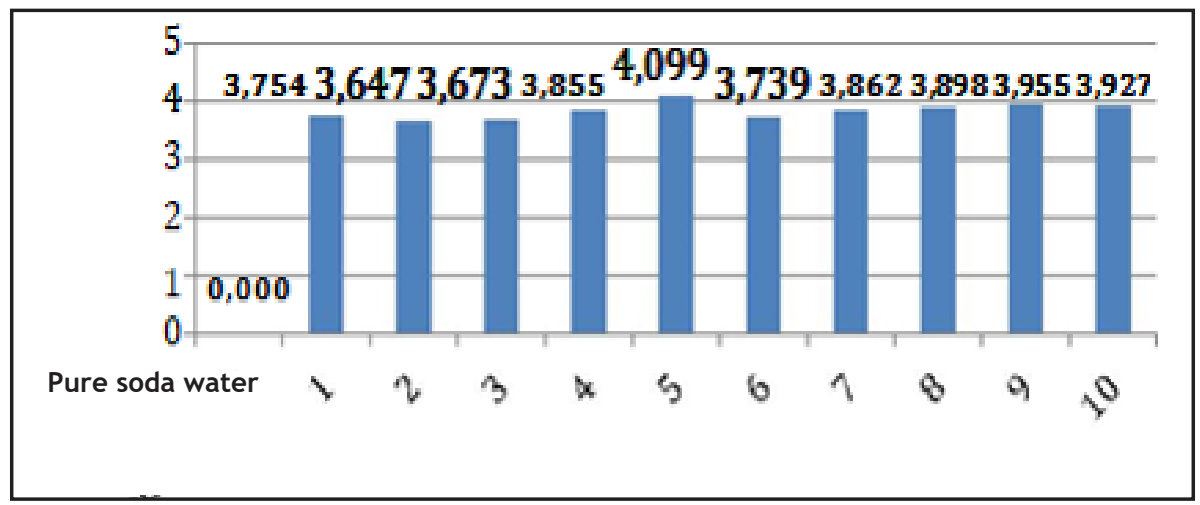

Calculation of SPSS Version 17 was performed on the release of calcium with one-sample test. Calculations of calcium released in the enamel surface immersed in soft drinks generated the $\mathrm{t}$-count value of 8.795 and the $\mathrm{t}$-table value of 2.085. Because the $\mathrm{t}$-count value was higher than the t-table value $(8.795<2.085)$, it can be concluded that soft drinks released calcium in the enamel surface. Calcium released on the surface of the enamel surface immersed in soda water produced a the $\mathrm{t}$-value of 9.936 and the $\mathrm{t}$-table of 2.085. The comparison result of the t-count and $t$-table values was similar with the value of soda water $(9.936>2.23)$, thus can be concluded that soda water could also release calcium in the enamel surface. The results of the statistical calculations above concluded that there both soft drink and pure soda water affect the calcium release in the enamel surface.

To determine whether there was a significant difference between the amount of calcium released from the surface of the enamel immersed in soft drinks (Coca Cola ${ }^{\circledR}$ ) and pure soda water, an independent sample t-test was carried out. Based on the calculation with SPSS Version 17, the t-count was 1.076 and the t-table was 2.085 . The $\mathrm{t}$-count value was lower than the $\mathrm{t}$-table value $(1.076<2.085)$, thus can be concluded that there was no significant difference between the amount of calcium released from the enamel surface immersed in pure soda water and soft drinks (Coca Cola ${ }^{\circledR}$ ).

\section{DISCUSSION}

The results of experimental studies on the effects of soft drinks on calcium release from enamel sur-faces are presented in Table 1 and 2 , which showed the presence of calcium release. This was indicat-ed by an increase in the amount of calcium released after soft drink immersion. The average amount of calcium released from the enamel surface after immersion in a soft drink was $4.122 \mathrm{ppm}$. The aver-age amount of calcium released from the enamel surface after immersion in pure soda water as con-trol was $3.492 \mathrm{ppm}$.

Calcium released due to acid exposure from soft drinks. Carbonated drinks have an 
average $\mathrm{pH}$ of 2.6 so that it can cause direct enamel demineralisation, which is indicated by the release of calcium follow-ing experiments that have been carried out. ${ }^{12,13}$ Drinks that cause tooth demineralisation are drinks that have a low $\mathrm{pH}$ below the enamel critical pH of 5.5 and have a high buffering capacity. The more acidic the drink will cause higher tooth enamel release.

Teeth exposed to carbonated drinks cause hydroxyapatite to diffuse out of the enamel. This causes hydroxyapatite to break down into $\mathrm{Ca} 2+$ and P043- ions. ${ }^{13,14}$ The amount of calcium released from tooth enamel is affected by the $\mathrm{pH}$ of the solution, buffer capacity, acid type, constant acid, immersion time, enamel type, salivary buffer ability, and solution temperature. ${ }^{12,15-17}$ Teeth exposed to carbonated drinks with acidic $\mathrm{pH}$ will experience calcium release as observed in the present research.

According to Lussi et al. ${ }^{18}$, other factors that can cause tooth erosion included acid type, chelating agent, the concentration of calcium, phosphate, and fluorine..$^{18}$ The type of acid in a solution affects tooth erosion. The acid contained in soft drinks that used in this study contains three kinds of acids, namely citric acid, phosphoric acid, and carbonic acid. The acid that most causes erosion is citric acid because citric acid can reduce the concentration of calcium ions in saliva. ${ }^{12,19}$ An ingredient known as chelating material can bind metal (ions) and remove it from the tissue. The chelating material in soft drinks can directly dissolve dental minerals. By eliminating acid or chelating substance can inhibit ero-sion of teeth. Some studies show that tooth erosion is associated with the method of drinking. Retain-ing drinks longer in the mouth can cause a more decrease of the $\mathrm{pH}$ in the oral cavity so that the acidic atmosphere develops. ${ }^{20}$ Clinical observations shows that the length of time a tooth contacts with an acidic environment is more prone to erosion than the volume of drinks consumed.

Based on the analysis of statistical tests using the independent $t$-test, there was no significant differ-ence between the treatment group that was immersed with soft drinks and the control groups which was immersed with pure soda water. The results showed that the calcium released from the crowns of teeth immersed with soft drink was higher than the crowns of teeth immersed with pure soda water. This was caused by the content and composition contained in soft drink (Coca Cola $\left.{ }^{\circledR}\right)$. This study used soft drink (Coca Cola ${ }^{\circledR}$ ) with an average $\mathrm{pH}$ of 2.6, and pure soda water with an average $\mathrm{pH}$ of 5 . This showed that cola brand soft drink (Coca Cola ${ }^{\circledR}$ ) was more acidic than soda water, but the difference was not too significant.

The results of our research showed that the potential erosion of soft drink was more considerable than pure soda water. Pure soda water causes tooth erosion, but its effect was very low, known as acid erosion. Pure soda water showed more significant calcium release than ordinary mineral water, but still lower than the level of soft drink. ${ }^{21}$

The release of calcium can cause demineralisation. Enamel demineralisation is the process of mineral loss from the chemical structure of enamel. Demineralisation of enamel occurs through the process of diffusion, which is the process of moving molecules or ions that dissolve in water to or from enamel to saliva due to the differences in the concentration of acidity of beverages on the enamel surface. The acidity of drinks having high concentrations and the initial $\mathrm{pH}$ of the low drinks will diffuse into the enamel, through the crystal lattice and enamel tubules that contain water and organic or protein matrix. ${ }^{13}$ Continuous demineralisation will cause erosion. ${ }^{22}$ Tooth erosion can occur as a result of constant contact or exposure between hard tooth tissue and acids sourced from the body or from outside the body. ${ }^{20}$ Theoretically, acid erosion from soft drinks is caused by low $\mathrm{pH}$ and high levels of phos-phoric acid in drinks. $\mathrm{pH}$ is not the only indicator in assessing the erosive potential of a drink. The effect of buffer capacity can cause tooth erosion. Buffer capacity is the amount of base needed to raise the $\mathrm{pH}$ of the drink to neutral $\mathrm{pH} .{ }^{23}$ The highest buffer capacity is found in fruit drinks, soft drinks, and pure soda water. Mineral water has the lowest buffer capacity. ${ }^{24}$

\section{CONCLUSION}

Soft drink affects the calcium release from the enamel surface. 


\section{REFERENCES}

1. Nanci A. Ten cate's oral histology: development, structure, and function. $3^{\text {th }}$ ed, St.Louis: CV. Mosby Co., 2008. p. 141-90.

2. Dorland. Dorland's Pocket Medical Dictionary (Dorland's Medical Dictionary). 26 $6^{\text {th }}$ ed. Philadelphia: Saunders-Elsevier; 2001.

3. Koerniati I. Perkembangan perawatan gigi masa depan. Padang: Andalas University Press. 2006.

4. Almatsier S. Prinsip dasar ilmu gizi. Jakarta: PT Gramedia Pustala Utama. 2005. p. 230 247,274.

5. Schroeder HE. Oral structural biology. New York: Thieme Medical Publishers Inc. 1991. p. 44-68.

6. National Soft Drink Association. Available from: http://nsda@softdrink.org.au [cited Jan 2012). 1991.

7. Widodo R. Mengenal minuman ringan berkarbonasi (Soft drink). Surabaya: Fakultas Industri Pangan Universitas 17 Agustus 1945 Surabaya. Available from: http: / / www.untag. ac.id/ [cited mar 2010] 2008.

8. Lussi A. Dental erosion from diagnosis to therapy. Switzerland:University of Bern. 2006.

9. Edwards M, Creanor SL, Foye RH, Gilmour WH. Buffering capacities of soft drinks: the potentional influence on dental erosion. J Oral Rehab 1999;26:923-7.

10. Larsen MJ, Nyvad B. Enamel erosion by some soft drinks and orange juices relative to their ph, buffering effect and contents of calcium phospate. Caries Res. 1999;33(1):81-7.

11. Schuurs AHB. Patologi gigi-geligi: kelainankelainan jaringan keras gigi. Yogyakarta: Gajah Mada University Press. 1992. p. 163-75.

12. Lloyd R. Acid in popular sodas erode tooth enamel. Available from: www.livescience.com [Cited Feb 2012]. 2007.

13. Prasetyo EA. Keasaman minuman ringan menurunkan kekerasan permukaan gigi. Maj Ked Gigi (Dent J). 2005;38(2):60-3.

14. Newburn E. Effectiveness of water fluoridation. J Public Health Dent 1989;49(5):279-89.

15. Mount GJ, Hume WR. Preservation and restoration of tooth structure. St. Louis. CV Mosby Co.1998. p. 10-14.

16. Amaechi BT, Higham SM, Edgar WM. Factor influencing the development of dentalerosion in vitro: enamel type, temperature and exposure time. J Oral Rehabil 1990;26(8):624-30.

17. Barbour ME, Finke M, Parker DM, Hughes JA, Allen GC, Addy M. The relationship between enamel softening and erosion caused by soft drinks at range of temperature. J Dent. 2006 Mar;34(3):207-13. Epub 2005 Aug 19.

18. Lussi A, Jaeggi T, Jaeggi-Schärer S. Prediction of the erosive potential of some beverages. Caries Res. 1995;29(5):349-54.

19. Tahmassebi JF, Duggal MS, Malik-Kotru G, Curzon ME. Soft drinks and dental health: A review of the current literature. J Dent. 2006 Jan;34(1):2-11. Epub 2005 Sep 12.

20. Cheng R, Yang H, Shao M, Hu T, Zhou X. 2009. Dental erosion and severe tooth decay related to soft drinks: A case report and literature review. China. J Zhejiang Univ Sci B. 2009 May;10(5):395-9.

21. Parry J, Shaw L, Arnaud MJ, Smith AJ. Investigation of minerals waters and soft drinks in relation to dental erotion. J Oral Rehabil. 2001 Aug;28(8):766-72.

22. Rensburg BG. Oral biology. Germany: Quintessence Publishing Co. Inc, 1995. p. 289. 99.

23. Jarvinen VK, A. Stabholz A, Wilkinson G. In vitro determineralization of erosion. J Dent Rest 1990;79(6):942-7.

24. Larsen MJ, Nyvad B. Enamel erosion by some soft drinks and orange juices relative to their ph, buffering effect and contents of calcium phospate. Caries Res. 1999;33(1):81-7. 